\title{
Transfer of Tritium Released into the Marine Environment by French Nuclear Facilities Bordering the English Channel
}

\author{
Bruno Fiévet, ${ }^{\dagger} *$ Julien Pommier, $^{\dagger}$ Claire Voiseux, ${ }^{\dagger}$ Pascal Bailly du Bois, ${ }^{\dagger}$ Philippe Laguionie ${ }^{\dagger}$ \\ Catherine Cossonnet, ${ }^{\S}$ and Luc Solier ${ }^{\dagger}$
} †Institut de Radioprotection et de Sûreté Nucléaire Laboratoire de Radioécologie de Cherbourg-Octeville, IRSN/PRP-ENV/SERIS,
Rue Max Pol Fouchet, BP 10, 50130 Cherbourg Octeville, France
${ }^{\S}$ Laboratoire de Mesure de la Radioactivité dans l'Environnement, IRSN/PRP-ENV/STEME, Bois des Rames - Bât 501, 91400 Orsay,
France

\section{Supporting Information}

ABSTRACT: Controlled amounts of liquid tritium are discharged as tritiated water (HTO) by the nuclear industry into the English Channel. Because the isotopic discrimination between $3 \mathrm{H}$ and $\mathrm{H}$ is small, organically bound tritium (OBT) and HTO should show the same $\mathrm{T} / \mathrm{H}$ ratio under steady-state conditions. We report data collected from the environment in the English Channel. Tritium concentrations measured in seawater HTO, as well as in biota HTO and OBT, confirm that tritium transfers from $\mathrm{HTO}$ to OBT result in conservation of the $\mathrm{T} / \mathrm{H}$ ratio $\left(\right.$ ca. $\left.1 \times 10^{-16}\right)$. The kinetics of the turnover of tritium between seawater HTO, biota HTO, and OBT was investigated. HTO in two algae and a mollusk is shown to exchange rapidly with seawater HTO. However, the overall tritium turnover between HTO and the whole-organism OBT is a slow process with a tritium biological half-life on the order of months. Nonsteady-state conditions exist where there are sharp changes in seawater HTO. As a consequence, for kinetic reasons, the T/H ratio in OBT may deviate transiently from that observed in HTO of samples from the marine ecosystem. Dynamic modeling is thus more realistic for predicting tritium transfers to biota OBT under nonsteady-state conditions.

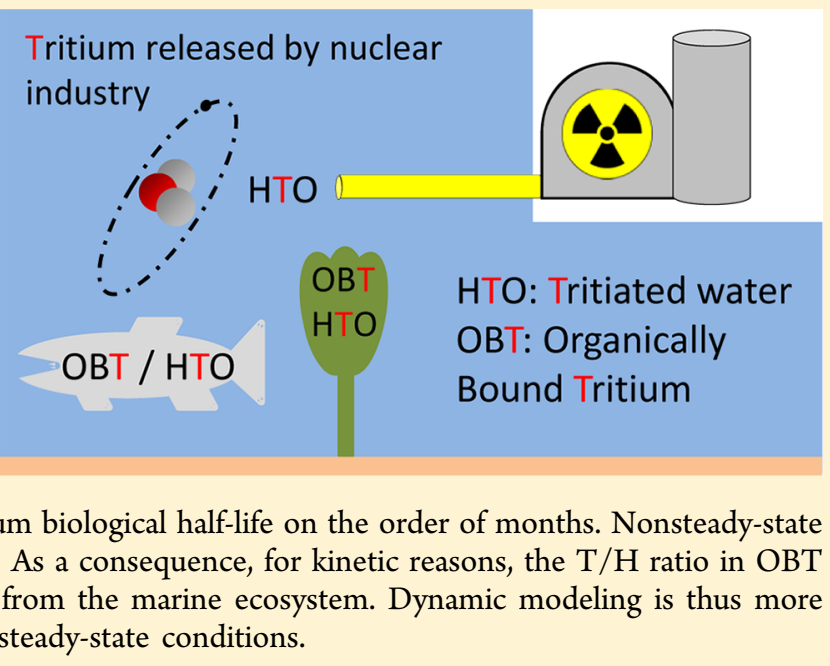

\section{INTRODUCTION}

The nuclear power plants (NPP) and the nuclear fuel reprocessing plant (RP) located on the French coast are two sources of controlled liquid radioactive discharges into the English Channel. Since the mid-1980s, nuclear facilities have significantly reduced the activities of most radionuclides in liquid effluents. Nevertheless, tritium is still widely released into the environment in proportion to industrial production, that is megawatts $(\mathrm{MW})$ of electricity generated and the quantities of nuclear fuel reprocessed. Tritium releases in the liquid effluents from all four NPPs account for less than $0.3 \mathrm{E} 15 \mathrm{~Bq} \cdot \mathrm{y}^{-1}$. Comparatively, controlled liquid releases of tritium from the RP amount to about $1 \mathrm{E} 16 \mathrm{~Bq} \cdot \mathrm{y}^{-1}$. In addition to a NPP located on the Seine River, which flows into the Channel, other sources of tritium entering the marine environment include fallout from natural production in the upper atmosphere and atmospheric nuclear weapon tests between 1945 and 1980 (UNSCEAR, 2000) as well as the nuclear facilities situated on the UK coast of the English Channel. Most anthropogenic tritium is produced as tritiated water (HTO). As soon as HTO reaches the natural environment, tritium enters the biogeochemical cycle of hydrogen. Tritium is incorporated into organic matter through physiological processes, such as photosynthesis, as well as tritium/hydrogen exchange with organic molecules. In this form, it is referred to as organically bound tritium (OBT). The turnover of tritium between water and organic matter results from many processes associated with a wide range of kinetics from almost instantaneous (acid base exchanges) to several months or maybe longer turnover rates (recycling of hydrogen from molecules/tissues). However, since tritium transfer between water and organic matter takes place through ${ }^{3} \mathrm{H} / \mathrm{H}$ exchange and photosynthesis, the isotopic ratio of tritium to hydrogen (referred to here as $\mathrm{T} / \mathrm{H}$ ) in OBT should tend to the same value as determined in water HTO. Theoretically, there are three reasons for an eventual difference in isotopic ratio between OBT and HTO. Because of the difference in nucleus mass, some reactions may discriminate in favor of tritium or hydrogen isotopes. Although this isotopic effect is known to occur, it is so far recognized as being only of minor importance. ${ }^{1-4}$ Finally, if this isotopic discrimination were really able to cause some $\mathrm{T} / \mathrm{H}$ shift, OBT and $\mathrm{HTO}$ would display different $\mathrm{T} / \mathrm{H}$ ratios even before the appearance of anthropogenic sources of tritium. A much more likely explanation for the difference in the $\mathrm{T} / \mathrm{H}$ ratio between $\mathrm{HTO}$ and $\mathrm{OBT}$ is related to the kinetics of hydrogen recycling and the

Received: February 28, 2013

Revised: $\quad$ May 3, 2013

Accepted: May 8, 2013 
occurrence of transient nonsteady-state situations in the natural environment. For instance, in the case of an accidental release, or in routine operations close to the sea outfall, water HTO activities can display sharp and highly dynamic variations implying that tritium exchanges between HTO and OBT are likely to be only partial. Thus, when HTO rises sharply, the transfer of tritium to OBT may lag behind and the isotopic ratio of the latter will be transiently lower than that in the water mass. Conversely, when HTO drops rapidly, clearance of OBT takes some time and the $\mathrm{T} / \mathrm{H}$ ratio may become temporarily higher in the OBT. Because tritium turnover rates in HTO and OBT imply that various processes are taking place over a wide range of rates, it remains a challenge of paramount importance for radioecologists to understand the apparent overall half-life (i.e., the biological half-life) of tritium between HTO and OBT. Finally, a much higher tritium labeling of OBT with respect to HTO could be explained if the original source of tritium is related to the synthesis of tritiated organic compounds rather than water. These types of compound are synthesized with a much higher isotopic ratio than that observed in environmental HTO. If these compounds (or their byproducts) reach the natural environment, they may be incorporated by living organisms, thus resulting in a strong labeling of OBT. This behavior also typically represents a nonsteady-state situation, and if hydrogen recycling of the highly tritiated molecules is not inhibited or slowed down (for instance, by trapping in the sediments) their tritium will progressively be diluted within the environment. This clearance will lead to a decrease in the isotopic ratio in organic matter down to values observed for HTO in the environment. Two well-known examples of such situations in the past are provided by the discharges from the GE Healthcare (formerly Amersham plc) radiopharmaceutical facility in Cardiff $\mathrm{Bay}^{5-9}$ and the use of tritiated paint in the clock industry and its impact on the sediments of the River Rhone. ${ }^{10,11}$ Thus, a knowledge of the chemical speciation of tritium releases is essential for our understanding of their impact on the environment.

The present study addresses the impact of tritium releases from French nuclear facilities on the marine environment in the English Channel with regard to the issues mentioned above. In particular, it focuses on a comparison between HTO and OBT and attempts to document accurately the turnover of tritium between seawater and local macroalgae. The transfer of tritium between water and biota is then discussed with respect to kinetics and with a view to operational modeling. The environmental measurement data presented here were collected as part of environment monitoring programmes operated in collaboration between IRSN and the operators AREVA NC and EDF.

\section{MATERIALS AND METHODS}

Tritium Measurements. Seawater samples were collected on the shore and immediately filtered at $0.2 \mu \mathrm{m}$. For samples collected around the Cotentin peninsula or farther East in the English Channel, $12 \mathrm{~mL}$ of scintillation liquid (Ultima gold LLT, PerkinElmer, Inc.) was added to $8 \mathrm{~mL}$ of filtered water in low background counting vials (PerkinElmer, Inc.) and counted for tritium activity for $16 \mathrm{~h}$ (Tricarb 2700TR, Quantasmart software, PerkinElmer, Inc.). The counter calibration was performed using a reference solution (TRY44, batch 134, Amersham plc). The detection limit was $2 \mathrm{~Bq} \cdot \mathrm{L}^{-1}$, which allowed detection of the impact of French nuclear facilities in the eastern part of the Channel. A few samples were collected near the shore in the western part of the English Channel and from the sea surface offshore in the Atlantic Ocean, where lower tritium levels were expected to occur. For these samples, 1L of seawater was stored in polyethylene bottles and analyzed by the Tritium Laboratory (Rosenstiel School of Marine and Atmospheric Science, University of Miami) for tritium activity. For all filtered seawater data, tritium is assumed to be in the form of tritiated water, HTO, and concentration is expressed in $\mathrm{Bq} \cdot \mathrm{L}^{-1}$. Accordingly, $1 \mathrm{~Bq} \cdot \mathrm{L}^{-1}$ as $\mathrm{HTO}$ corresponds to a $\mathrm{T} / \mathrm{H}$ ratio of $8.1 \times 10^{-18}$.

Biota samples collected from the marine environment were freeze-dried. Water was recovered to measure free HTO, taking $10 \mathrm{~mL}$ and adding $10 \mathrm{~mL}$ of scintillation liquid, and then counting (the different ratios of $10 / 10$ and $8 / 12$ are due to the salt present in seawater). The dry material was stored in aluminized plastic vacuum-sealed bags and kept at $-20{ }^{\circ} \mathrm{C}$ until processing for OBT analysis at the Laboratoire de Mesure de la Radioactivite dans l'Environnement (LMRE, Orsay, France). Freeze-dried organic matter was completely oxidized by combustion trapping the hydrogen and tritium in the form of combustion water. Thus, OBT was transformed into water allowing tritium measurement by scintillation counting, exactly as with HTO. OBT activity is expressed in $\mathrm{Bq} \cdot \mathrm{L}^{-1}$ of combustion water. Comparing OBT and $\mathrm{HTO}$ in the same units is equivalent to comparing $\mathrm{T} / \mathrm{H}$ isotopic ratios. This procedure allowed us to address accurately the question of a possible alteration in the $\mathrm{T} / \mathrm{H}$ ratio during the transfer of tritium between water HTO and OBT.

The dry/wet weight ratio $(d / w)$ of the samples was determined in parallel. Assuming an average mass percentage of $6 \%$ hydrogen in dry organic matter, $100 \mathrm{~g}$ should yield $54 \mathrm{~g}$ of combustion water. Therefore, for radioprotection purposes, this allows us to estimate the tritium concentration $\left(\mathrm{Bq} \cdot \mathrm{kg}^{-1}\right.$ wet weight basis) in the original sample as follows:

$$
\begin{aligned}
{\left[{ }^{3} \mathrm{H}\right]_{\text {wet sample }}=} & (1-d / w) *\left[{ }^{3} \mathrm{H}\right]_{\mathrm{HTO}} \\
& +\mathrm{H} \% * 0.09 *(d / w) *\left[{ }^{3} \mathrm{H}\right]_{\mathrm{OBT}}
\end{aligned}
$$

Hydrodynamic Modeling of Tritium Dispersion. The location of the dispersion plume of liquid tritium discharges from the AREVA NC reprocessing plant at La Hague was predicted by using a hydrodynamic model. The calculations were performed using a well validated code as previously described. ${ }^{12,13} \mathrm{~A}$ detailed description of this model is beyond the scope of this study, and the reader is invited to refer to the relevant literature cited here. It should be stressed, however, that real discharges, tidal currents, and wind conditions were used as input data to this model, which yields realistic concentration predictions. This tool was used to produce maps of the plume at particular dates of interest or a time series of calculated seawater HTO at a given location. These model predictions were compared with the field measurement data reported here.

Estimation of Tritium Turnover between Seawater HTO and Biota OBT. The overall turnover of tritium between seawater and two species of intertidal seaweed (Fucus serratus and Laminaria digitata) was investigated using the same technique as previously described in details. ${ }^{14}$ Briefly, a discrete input signal denoted as $e(i)$ was built from the time-series measurements in seawater and a discrete output signal denoted as $s(i)$ was built from the time-series measurements in the biological compartment. The model equation $s(i)=a s(i-1)+b e(i)$ was fitted to the signals e and $s$, thus yielding the optimal values of parameters $a$ and $b$ corresponding to the best fit. The steady-state concentration factor $\left(\mathrm{CF}_{\mathrm{s}}\right)$ and the biological half-life $\left(\mathrm{tb}_{1 / 2}\right)$ for the radionuclide were computed as follows, using the values of parameters $a$ and $b$, the sampling period $T$, the time interval between $t(i-1)$ and $t(i)$ : 

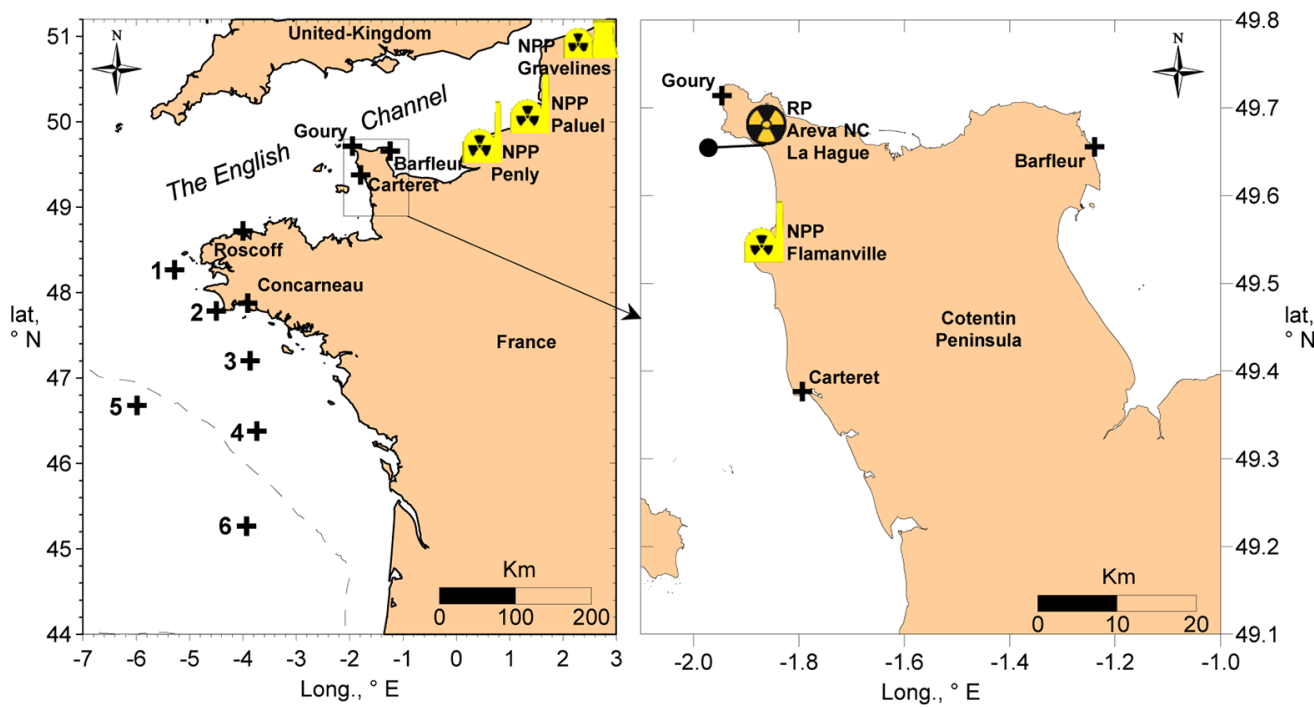

Figure 1. Maps showing location of nuclear facilities responsible for tritium liquid releases on the French coast of the Channel (NPP, nuclear power plant; RP, nuclear fuel reprocessing plant) and the sampling locations (vertical crosses). The solid line with a filled circle at its seaward end represents the outfall from the RP and the dashed line shows the continental shelf border.

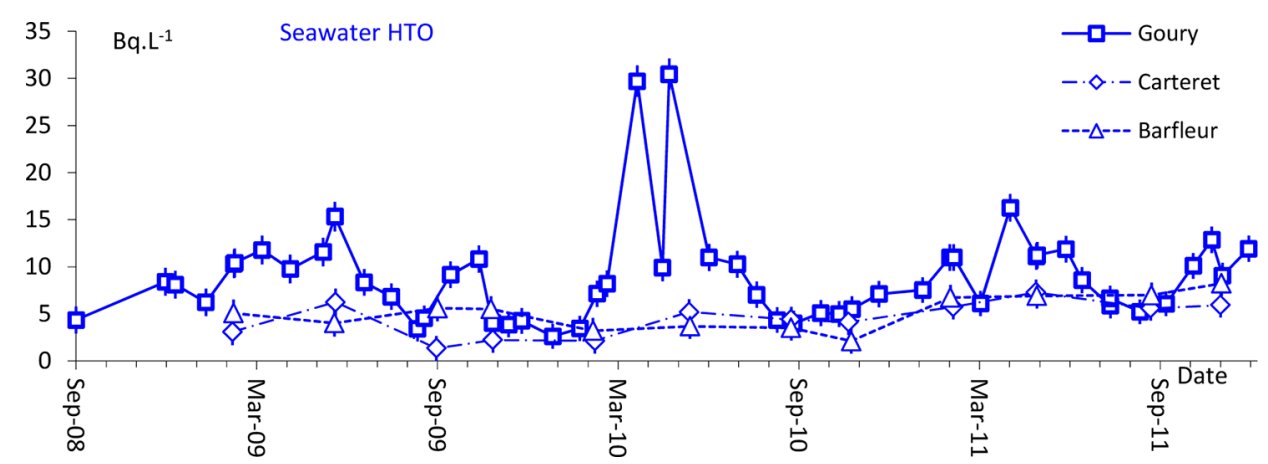

Figure 2. Time-series showing measurements of tritium (HTO) activity in seawater collected around the Cap de La Hague. Values are expressed in $\mathrm{Bq} \cdot \mathrm{L}^{-1}$, error bars indicate measurement uncertainties (2 sigma).

$$
\mathrm{CF}_{\mathrm{s}}=b /(1-a) \text { and } \mathrm{tb}_{1 / 2}=\operatorname{Ln}(2) /\left(-\operatorname{Ln}(a) / T-k_{\mathrm{p}}\right)
$$

where $k_{\mathrm{p}}$ is the radioactive decay constant of the radionuclide. Data processing were performed using R environment software ${ }^{15}$ available at http://www.R-project.org/. The model equation was fitted to the signals $e$ and $s$ using the $R$ function optim(). The $n l s()$ and $n l s B o o t()$ functions from library nlstools for $R^{16}$ were used to estimate $95 \%$ confidence intervals on the values of $\mathrm{CF}_{s}$ and $\mathrm{tb}_{1 / 2}$.

\section{RESULTS}

Figure 1 shows the different locations where seawater and/or biota samples were collected.

In July-Sept 2010, two seawater samples were collected near the coast at Concarneau and Roscoff, at the same time as some sea-surface samples farther offshore in the Atlantic. These samples provide us with information about the background activity levels in waters entering the Western English Channel; the data ranging from 0.1 to $0.2 \mathrm{~Bq} \cdot \mathrm{L}^{-1}$ are presented in Table S1 of the Supporting Information.

Because the major source of tritium input to the marine environment is situated on the North Cotentin Peninsula, data were collected by seawater sampling in the surrounding coastal areas. We focus our study on Goury, where seawater HTO measurements were performed at least every month between Sep. '08 and Dec. '11 (Figure 2). From Feb. '09 to Nov. '11, seawater samples were also collected every three months at Carteret and Barfleur (40 km South and $50 \mathrm{~km}$ East of Goury, respectively). The wide fluctuations of seawater HTO call into question whether monthly sampling is appropriate to capture accurately the time variability of the HTO signal (Figure 2). To address this issue in greater detail, HTO activities in seawater at Goury were monitored every $10 \mathrm{~min}$ for 6 days from the 24th to 29th of June, 2009 (Figure 3). These high-frequency measurements were carried out in parallel with the prediction of dispersion of HTO originating from liquid discharges from the RP of AREVA-NC at La Hague, as computed by a hydrodynamic model (Figure 3). The highs and lows in HTO activity measured at Goury coincide with the location of the plume predicted by the model, both close to the shore and farther offshore, in cases where seawater samples were collected. Furthermore, the plume dispersion model is used to compute HTO activities at Goury every $10 \mathrm{~min}$ from Jan. '09 to Dec. ' 11 . The calculated values are then compared with monthly field measurements. In this way, we can assess the information obtained by monthly sampling with respect to the predicted instantaneous changes in seawater HTO signal at Goury (Figure S1 of the Supporting Information).

In parallel with HTO measurements in seawater at Goury, HTO, and OBT activities were monitored every month in Fucus serratus and Laminaria digitata collected at the same location. By fitting the dynamic transfer model equation (Methods section for 


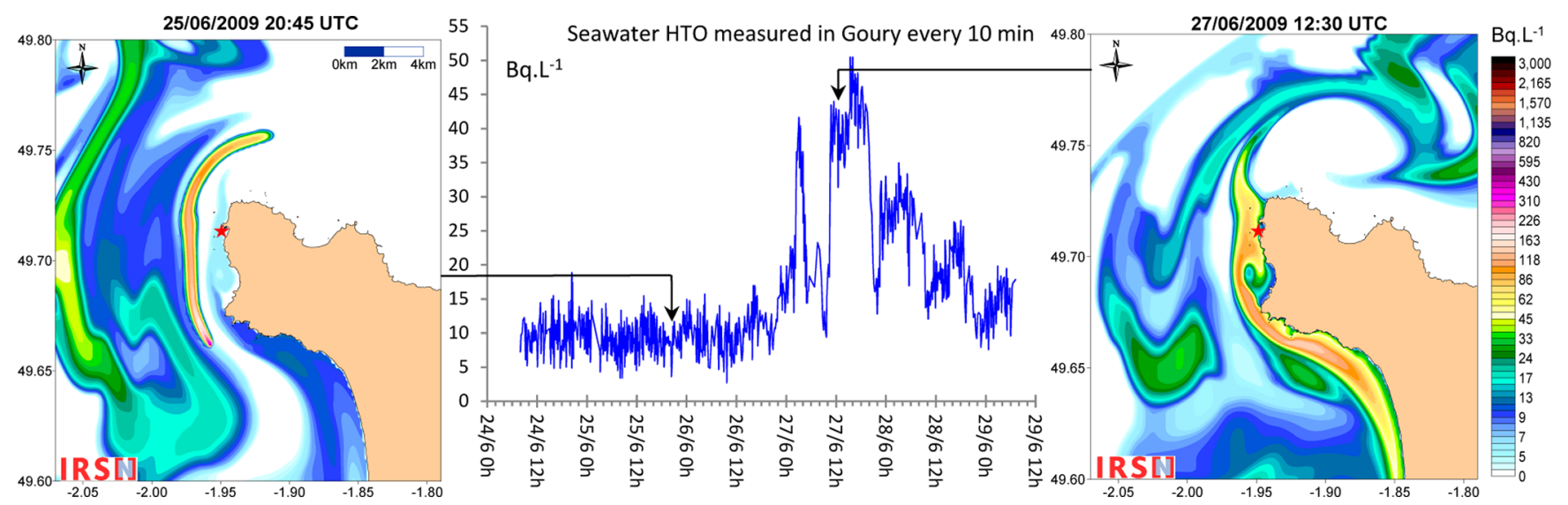

Figure 3. Graph at center: time-series showing measurements of tritium (HTO) in seawater collected every 10 min at Goury. Maps on each side show tritium plume predicted by the dispersion model on 25/06/2009 at 20:45 (Left), when seawater HTO was around $10 \mathrm{~Bq} \cdot \mathrm{L}^{-1}$ at Goury (red star), while the plume was far away from the shore, and on 27/06/2009 at 12:30 (Right), during a peak episode above $30 \mathrm{~Bq} \cdot \mathrm{L}^{-1}$ at Goury, while the plume was in contact with the sampling point.
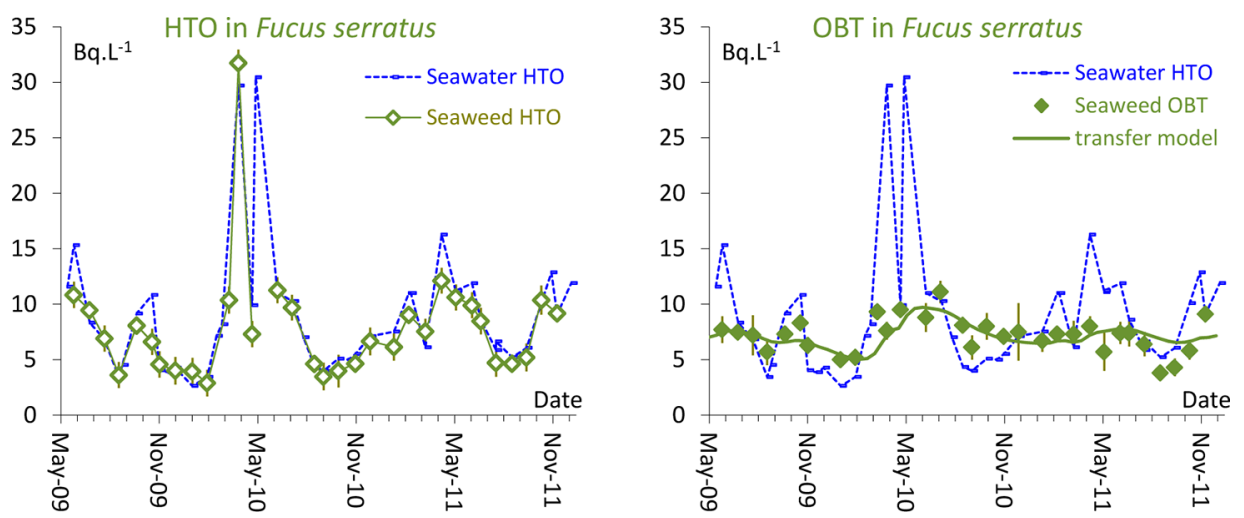

Figure 4. Time-series measurements of tritium in seaweed Fucus serratus collected at Goury (Left, HTO; right, OBT). Values are expressed in Bq· $\mathrm{L}^{-1}$, error bars account for measurement uncertainties ( 2 sigma). Seawater HTO data (dashed line) reported from Figure 2 used as input signal to the model to compute OBT in seaweed (solid line).

details) to seawater HTO data as the input signal (e) and seaweed OBT data as the output signal (s), we can obtain the optimal values for parameters $\mathrm{a}$ and $\mathrm{b}$. The sampling period $\mathrm{T}$ is 15 days and the radioactive decay constant of tritium is taken as $0.000154 \mathrm{~d}^{-1}$. The data are presented on Figure 4 for F. serratus and Figure S2 of the Supporting Information for L. digitata along with seawater HTO for comparison. The resulting computed values for the steady-state concentration factor $\left(\mathrm{CF}_{s}\right)$ and the biological half-life of tritium $\left(\mathrm{tb}_{1 / 2}\right)$ are given in Table 1 . Another

Table 1. Dynamic Transfer Parameters between Seawater HTO and Two Species of Brown Seaweed OBT, Derived from Field Measurements: Confidence Intervals (95\%) Are Given in Square Brackets

\begin{tabular}{lll} 
& \multicolumn{1}{c}{ Fucus serratus } & Laminaria digitata \\
$\mathrm{CF}_{\mathrm{s}}$ & $0.78[0.76-0.82]$ & $0.89[0.86-0.92]$ \\
$\mathrm{tb}_{1 / 2}, \mathrm{~d}$ & $128[99-175]$ & $118[95-152]$ \\
\hline
\end{tabular}

series of tritium activity measurements was carried out at the same location (Goury) in Patella sp, a grazing mollusc representing a higher trophic level. This time-series is presented in Figure S2 of the Supporting Information.

To investigate the behavior of the $\mathrm{T} / \mathrm{H}$ isotope ratio at various trophic levels, HTO and OBT activities were measured in various

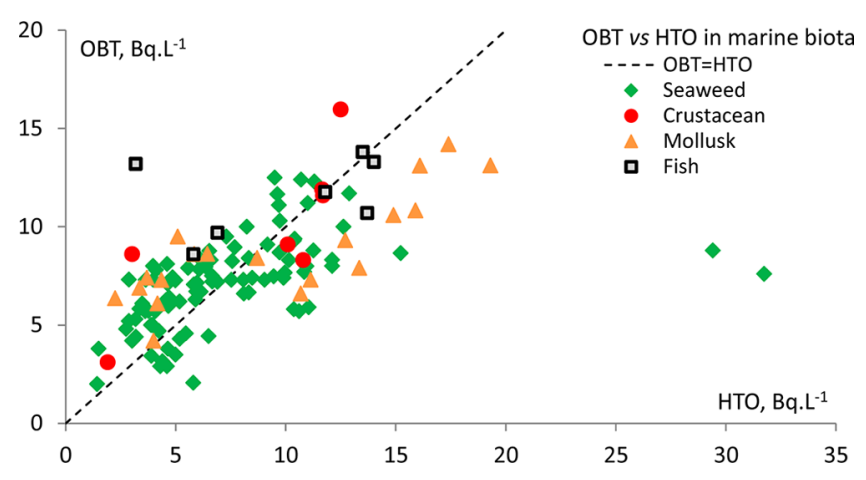

Figure 5. Relation between OBT and HTO in marine biota collected around the North Cotentin coast. Dashed line corresponds to equal isotope ratios $(\mathrm{T} / \mathrm{H})$ in $\mathrm{HTO}$ and OBT.

marine organisms collected over the past decade in the North Cotentin area. The data are presented in Figure 5 (uncertainties are omitted for reasons of clarity). Table 2 reports the mean OBT/HTO ratios calculated by group of biota and also combined together. Using the approach proposed in the method section, the ranges of tritium concentration in the whole organism are expressed in $\mathrm{Bq} \cdot \mathrm{kg}^{-1}$ wet weight of sample.

Facing the English Channel, there are four NPPs located on the French coast, at Flamanville, Paluel, Penly, and Gravelines 
Table 2. OBT/HTO Ratio and Ranges of Tritium Concentrations in Whole Organism $\left(\mathrm{Bq} \cdot \mathrm{kg}^{-1} \mathrm{Wet}\right)$ Observed in Marine Biota around the Cotentin Peninsula Coast

\begin{tabular}{lrcc} 
& $n$ & OBT $/$ HTO mean $\pm \mathrm{s}$ & {$\left[\right.$ Tritium] Bq.kg ${ }^{1-} \mathrm{w}$} \\
seaweed & 94 & $1.1 \pm 0.4$ & {$[1.4-26.4]$} \\
mollusk & 19 & $1.2 \pm 0.6$ & {$[2.5-16.1]$} \\
crustacean & 7 & $1.3 \pm 0.7$ & {$[1.8-10.4]$} \\
fish & 7 & $1.5 \pm 1.2$ & {$[4-12.6]$} \\
all & 127 & $1.2 \pm 0.5$ & {$[1.4-26.4]$} \\
\hline
\end{tabular}

(Figure 1). Samples of sessile marine biota (brown seaweed, mussel, and limpet) were collected in close proximity to these facilities between 2001 and 2011. Figure 6 presents the activities of HTO and OBT measured in these samples of biota (uncertainties are omitted for reasons of clarity). The general direction of water circulation in the Channel is from SW to NE, so we can discriminate between data from locations upstream $(10-60 \mathrm{~km})$ or downstream $(0.1-16 \mathrm{~km})$ of the NPPs. ${ }^{17}$ These data points are represented as open and filled symbols, respectively. The sampling sites can be distinguished as either or not being influenced by the liquid releases from a given NPP.

\section{DISCUSSION}

The North Cotentin area hosts the AREVA NC spent fuel RP at La Hague, the NNP of Flamanville (EDF), a nuclear waste storage site (ANDRA), and a naval shipyard industry involving nuclear propulsion (DCNS). The main source of controlled tritium liquid discharge to the marine environment is the $R P$ $\left(1 \mathrm{E} 16 \mathrm{~Bq} \cdot \mathrm{y}^{-1}\right)$, which represents about 100 times the input from a NPP, the two other sources being hardly detectable.

We first focus on seawater tritium concentrations in the vicinity of the reprocessing plant, where the average activity level in the near shore zone is around $10 \mathrm{~Bq} \cdot \mathrm{L}^{-1}$, with occasionally higher values $\left(>30 \mathrm{~Bq} \cdot \mathrm{L}^{-1}\right)$.
Tidal currents around the Cotentin coast are very strong (up to $5 \mathrm{~m} \cdot \mathrm{s}^{-1}$ ), and the local hydrodynamics lead to a rapid dispersion and dilution of liquid discharges from the facilities. An accurate and realistic hydrodynamic model allows us to predict the dispersion of soluble substances with suitable temporal/spatial resolution using discharges as well as tide and wind data. ${ }^{12,13}$ This model has been extensively validated by matching several tens of thousand measured/calculated values and provides a tool to support the interpretation of field measurement data. For example, the enhanced seawater tritium levels measured at Goury can be elucidated by the following essential information: When the plume is located off-shore, tritium concentrations measured every $10 \mathrm{~min}$ on the coast are around $10 \mathrm{~Bq} \cdot \mathrm{L}^{-1}$, which corresponds to the level routinely recorded in seawater near the shore around the Cap de La Hague. However, higher levels (several tens of Bq. $\mathrm{L}^{-1}$ ) are observed at Goury when the plume sometimes comes into contact with the shoreline (Figure 3 ). Thus, the question arises as to whether seawater tritium measured on a monthly basis provides an accurate and appropriate basis to investigate tritium transfers between seawater and biota. Some indication is given by matching monthly field data with concentrations calculated every $10 \mathrm{~min}$ (Figure S1 of the Supporting Information). It can be noticed that the lowest values ( $\mathrm{ca} .5 \mathrm{~Bq} \cdot \mathrm{L}^{-1}$ ) are observed in late summer 2009 and 2010 or autumn-winter 2009, whereas the model predicts relatively stable low levels. Intermediate values (ca. $10 \mathrm{~Bq} \cdot \mathrm{L}^{-1}$ ) are found even though the model predicts a more noisy pattern, with the plume occasionally reaching the shore. The highest HTO values are measured in spring $2010\left(>30 \mathrm{~Bq} \cdot \mathrm{L}^{-1}\right)$, in agreement with the very noisy patterns for several months predicted by the model. This data comparison is useful because it gives an indication of the underlying factors affecting the monthly field measurements. This is of particular importance with respect to kinetics if the source term signal can be considered as an input for transfer modeling. The other data points from farther away to the South and East (Figure 2, Carteret and Barfleur, respectively) are compatible with the
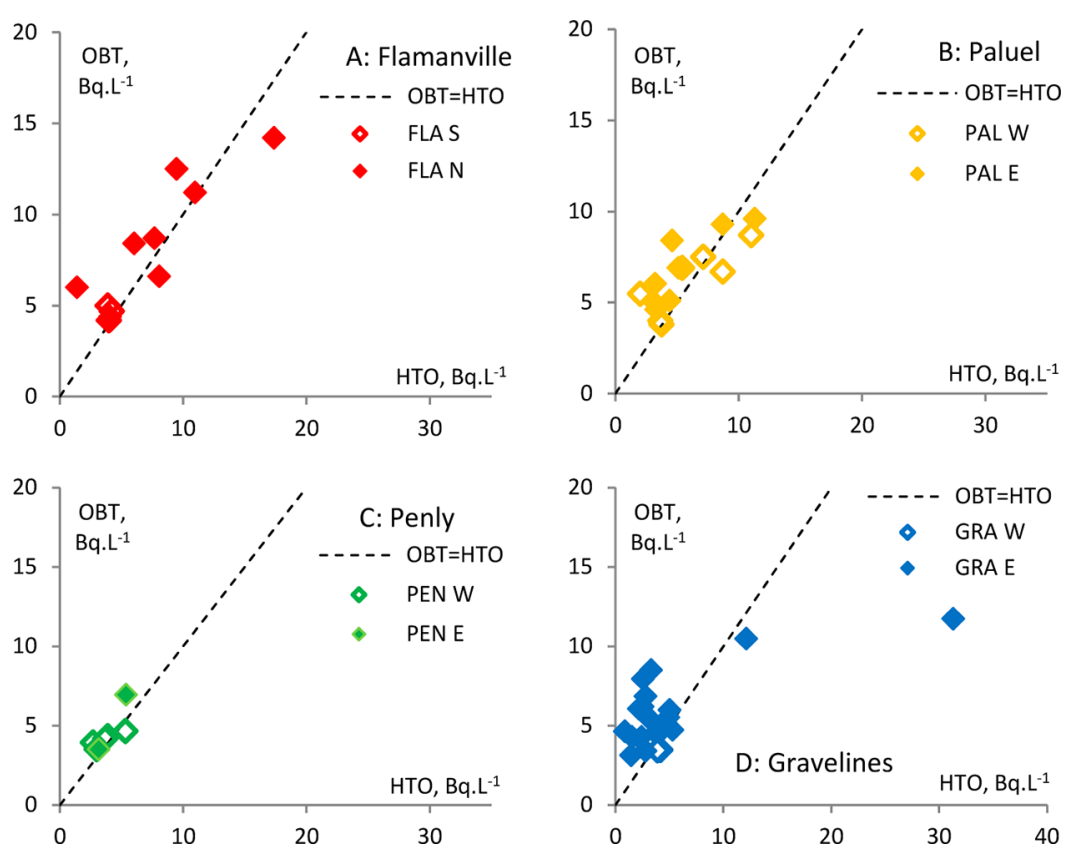

Figure 6. Relation between OBT and HTO in sessile marine biota collected on the shore (North, South, East, and West) around the NPPs (A, Flamanville; B, Paluel; C, Penly; D, Gravelines) located on the French coast of the Channel. Open or filled symbols: upstream or downstream sampling locations, respectively. Dashed line corresponds to equal isotopic ratios $(\mathrm{T} / \mathrm{H})$ in HTO and OBT. 
dilution of radionuclide discharges in the area as inferred from observations and predicted from hydrodynamic modeling. ${ }^{12,13,18}$ At greater distances from the RP outfall, mixing and dilution result in more stable seawater HTO compared to the sharp changes observed at Goury.

The transfer of tritium between seawater and seaweed was investigated at Goury by considering two biota compartments. The internal water from seaweed was extracted by freeze-drying to determine HTO, and the dry material (including organic matter) was analyzed for OBT. The HTO data presented on Figure 4 and Figure S2 of the Supporting Information show closely similar values for seawater and seaweed. This clearly demonstrates that seaweed and seawater HTO exchange takes place rapidly leading to a steady state between the two compartments. A much shorter sampling period would be required to investigate the kinetics of water turnover between the seaweed and the seawater. However, it should be stressed that F. serratus grows in the middle part of the intertidal zone, whereas L. digitata grows in the deepest part. Consequently, the former species is exposed to the atmosphere for several hours twice a day, whereas the latter is only exposed for a few hours twice a month. Interestingly, this difference allows us to check for the eventual influence of HTO exchanges between seaweed and water from the atmosphere (or rain). In both species, seaweed water HTO closely matches seawater HTO, irrespective of its time of emergence at low tide. This suggests that exchange with atmospheric HTO is small compared to seawater HTO. Conversely, the data presented in Figure 4 and Figure S2 of the Supporting Information clearly display a smoothing of seaweed OBT with respect to seawater HTO changes because of the slow transfer kinetics between these two compartments. Data processing using the method described in ${ }^{14}$ allows us to estimate the concentration factor between seaweed OBT and seawater HTO, as well as the biological half-life of tritium (Table 1). To date, there is no statistical method that yields standard deviation and confidence intervals on $\mathrm{CF}_{s}$ and $\mathrm{tb}_{1 / 2}$. The normal distribution of the residuals is checked statistically (Shapiro test), and homogeneity is assessed graphically (not shown here). Then, a statistical analysis is carried out using the bootstrap technique $^{16}$ to provide confidence intervals $(95 \%)$ on the transfer parameters $\left(\mathrm{CF}_{\mathrm{s}}\right.$ and $\left.\mathrm{tb}_{1 / 2}\right)$. If the isotopic $\mathrm{T} / \mathrm{H}$ ratio were the same in seaweed OBT and in seawater $\mathrm{HTO}$, then the $\mathrm{CF}_{\mathrm{s}}$ value should be equal to unity. The $\mathrm{CF}_{\mathrm{s}}$ values presented in Table 1 are close to but a little less than unity, which suggests a slightly lower $\mathrm{T} / \mathrm{H}$ ratio in seaweed OBT than in seawater HTO. A possible influence of HTO exchange with atmospheric water depleted in tritium is not obvious, as discussed above. Although isotopic discrimination might be possible, the reason for this slightly lower tritium level in seaweed OBT with respect to HTO remains to be clarified.

Limpets can be considered as sessile organisms that can be used to reduce the bias of the uncertainty on HTO levels in the surrounding environment. Limpets were sampled every three months for analyses of HTO and OBT in their soft tissues, as also carried out for seaweed (Figure 3). Despite the lower frequency of sampling, the data show that limpet HTO closely matches seawater HTO. This indicates that, as for seaweed, water exchange is rapid between seawater and limpet cells. However, limpet OBT clearly smoothes out the changes in HTO like seaweed OBT. The three-month sampling period is too long to derive an accurate estimate of $\mathrm{tb}_{1 / 2}$ from this time series. Nevertheless, these data give some indication on how to deal with a higher level of the food chain. Although limpets feed on algae, we observe very similar HTO and OBT patterns as in seaweed. A major component of tritium transfer to biota is likely to involve the cellular water HTO compartment. Cell membranes are permeable to water, which can pass through water channels. Homeostasis is mainly achieved through the regulation of solute transport driving osmotically controlled water movements. ${ }^{19-23}$ Because limpet HTO rapidly reaches a steady state with seawater HTO, studying the partition of tritium between seawater HTO and limpet OBT is a realistic approach to modeling tritium transfer between biota and seawater. Even if this approach does not take account of all potential pathways for tritium transfer between the two compartments, it may be reliable enough for operational modeling purposes. For upper levels of the food web, in particular predators cellular HTO is also expected to undergo rapid exchange with seawater HTO. Thus, to model tritium transfer between seawater HTO and OBT in biota, we need to address two key issues: First, the OBT/HTO ratio, which indicates whether tritium is enriched during its transfer between seawater and organic matter. And second, the biological half-life $\left(\mathrm{tb}_{1 / 2}\right)$ between seawater HTO and OBT in biota, which should be taken into account for sharp changes in seawater HTO, in the event of an accident or close to a source of input. The environment data collected so far in the English Channel confirms that the isotopic ratio $\mathrm{T} / \mathrm{H}$ is similar in OBT as in HTO. Using samples collected at Goury, where there are rapid changes in seawater HTO activity, the $\mathrm{CF}_{\mathrm{s}}$ values obtained for macroalgae are close to unity. Plots of OBT versus HTO for several groups of marine biota sampled in the North Cotentin area show data points scattered around the perfect correlation line corresponding to an OBT/HTO ratio of 1 (Figure 5). Seaweed outlier values correspond to the high levels of HTO (ca. $30 \mathrm{~Bq} \cdot \mathrm{L}^{-1}$ ) observed in April 2010 in Fs and $L d$, whereas OBT activity remains low (Figure 4 and Figure S2 of the Supporting Information). Another outlier is observed in a flat fish caught $3 \mathrm{~km}$ from the sea outfall yielding an OBT value of $13.2 \mathrm{~Bq} \cdot \mathrm{L}^{-1}$ and a low $\mathrm{HTO}$ activity $\left(3.2 \mathrm{~Bq} \cdot \mathrm{L}^{-1}\right)$ compared to the average level in this area $\left(\mathrm{ca} .10 \mathrm{~Bq} \cdot \mathrm{L}^{-1}\right)$. Indeed, the hydrodynamic model predicted low seawater HTO $\left(<5 \mathrm{~Bq} \cdot \mathrm{L}^{-1}\right)$ during the days preceding capture of the flat fish. These outliers illustrate how OBT in nonsteady-state biota can deviate from the perfect correlation line. Mobility of species clearly also adds to the bias because of the uncertainty on HTO in the surrounding environment before their capture. Nevertheless, the average ratio between OBT and HTO (which also compares the $\mathrm{H} / \mathrm{T}$ isotopic ratio) is not significantly different from 1 (Table 2). This confirms that no significant tritium enrichment occurs during its transfer from seawater to biota.

By examining OBT versus HTO in English Channel waters, we are able to detect the contribution of NPPs. Tritium liquid discharges from one NPP are 2 orders of magnitude lower than those from the RP of La Hague. Moreover, in the French coastal waters between the Cap de La Hague and the Straits of Dover (Eastern end of the Channel) the hydrodynamic dilution factor (DF) is only of the order of 2.5. ${ }^{12,17}$ Thus, in the English Channel, the impact of the RP is dominant over other sources. On the basis of dilution factors obtained from previous studies, ${ }^{12}$ it is possible to assess the impact of the RP at the four NPP sites. The majority of values for HTO and OBT attain levels of up to 20 and $15 \mathrm{~Bq} \cdot \mathrm{L}^{-1}$, respectively (Figure.6). Dilution factors of 1.0, 1.9, 2.2, 2.5 are taken to account to assess the RP impact at Flamanville, Paluel, Penly, and Gravelines, respectively. ${ }^{12,17}$ Sampling was carried out in the close vicinity of the NPPs. At Flamanville, the tritium input from the NPP is masked because it is very close to the RP (Figure 6A). At Paluel, the dilution of the RP impact (DF 1.9) should result in HTO and OBT values below 11 and $8 \mathrm{~Bq} \cdot \mathrm{L}^{-1}$, respectively. Upstream data 
(open symbols) are in agreement with this estimation. Downstream data (filled symbols) around $10 \mathrm{~Bq} \cdot \mathrm{L}^{-1}$ tend to suggest some input from the Paluel NPP (part B of Figure 6). At Penly, the dilution of the RP impact (DF 2.2) should yield HTO and OBT values below 9 and $7 \mathrm{~Bq} \cdot \mathrm{L}^{-1}$, respectively. The input of tritium from the Penly NPP remains undetectable compared to that of the RP (part C of Figure 6). However, it is noteworthy that, with increasing distance from the RP, OBT and HTO are expected to approach a steady state. This is supported by upstream data (open symbols) from the Penly NPP, which are assumed to result from the predominant impact of the RP showing a fairly close match with the perfect correlation line $(\mathrm{OBT} / \mathrm{HTO}=1)$. Finally, at Gravelines, HTO and OBT values related to the RP releases are expected to fall below 8 and 6 $\mathrm{Bq} \cdot \mathrm{L}^{-1}$, respectively. In the vicinity of Gravelines, the imprint of the tritium releases from this NPP is detectable over the RP background. This interpretation is clearly supported by outlier values of $\mathrm{HTO}$ around $30 \mathrm{~Bq} \cdot \mathrm{L}^{-1}$ and OBT over $10 \mathrm{~Bq} \cdot \mathrm{L}^{-1}$ (part D of Figure 6). As in other NPP sites, upstream data are expected to reflect OBT/HTO transfer from distant sources of input and would thus be close to a steady state. This hypothesis is corroborated by data points (open symbols) close to the perfect correlation line. Nevertheless, it should be emphasized that the impact of the NPPs can only be detected provided the sampling points are close to the effluent outlets $(<10 \mathrm{~km})$. Besides, the present data demonstrate that the monitoring program undertaken in the vicinity of the NPPs including OBT, which integrates variations of tritium over time, is well adapted and accurate for assessing the specific radiological impact of these facilities on the marine environment.

The major contribution to tritium activity in biota and seafood is HTO (calculation in the Methods section). Data reported in Table 2 illustrate the maximum values observed in close proximity to the sources of input on the Channel coast. However, because of the rapid dispersion and dilution taking place off the Cotentin Peninsula, the levels of HTO and OBT in the Channel marine environment are generally lower than $10 \mathrm{~Bq} \cdot \mathrm{L}^{-1}$. With respect to human radioprotection, this level can be compared with the limit of $10000 \mathrm{~Bq} \cdot \mathrm{L}^{-1}$ recommended by the WHO for drinking water. ${ }^{24}$ With regard to the impact on marine biota, experiments have been undertaken over the past decade to investigate the potential impact of chronic exposure to low doses of tritium in marine species. ${ }^{25-30}$ Dose rates as low as $10 \mu \mathrm{G} . \mathrm{h}^{-1}$ are shown to cause genotoxic damage in the blue mussel. However, such dose rates would correspond to tritium levels in seawater on the order of $1 \mathrm{E} 6 \mathrm{~Bq} \cdot \mathrm{L}^{-1}$, which is far above the tritium levels encountered in the natural marine environment of the English Channel.

\section{ASSOCIATED CONTENT}

\section{(5) Supporting Information}

Background tritium levels in seawater entering the English Channel; comparison between monthly field measurement of seawater HTO at Goury and hydrodynamic modeling every $10 \mathrm{~min}$; parallel seaweed data in Laminaria digitata collected at Goury, as in Fucus serratus; HTO and OBT data in Patella sp. collected at Goury. This material is available free of charge via the Internet at http://pubs.acs.org.

\section{AUTHOR INFORMATION}

\section{Corresponding Author}

*Tel: +33233014101, fax: +33233014130, e-mail: bruno.fievet@ irsn.fr.

\section{Notes}

The authors declare no competing financial interest.

\section{ACKNOWLEDGMENTS}

The authors are indebted to Professor Pascal Morin who provided Atlantic offshore seawater sample. This work was funded in part by the European Regional Development Fund, INTERREG IVa (Grant No. 4059). Dr. M.S.N. Carpenter postedited the English style.

\section{REFERENCES}

(1) Baumgärtner, F.; Kardinal, C.; Müllen, G. Distribution of tritium between water and exchangeable hydrogen bridges of biomolecules. J. Radioanal. Nucl. Chem. 2001, 249 (2), 513-517.

(2) Campbell, B. J.; Li, C.; Sessions, A. L.; Valentine, D. L. Hydrogen isotopic fractionation in lipid biosynthesis by $\mathrm{H} 2$-consuming Desulfobacterium autotrophicum. Geochim. Cosmochim. Acta 2009, 73 (10), 2744-2757.

(3) Chih, H.-W.; Neil, E.; Marsh, N. Tritium partitioning and isotope effects in adenosylcobalamin-dependent glutamate mutase. Biochemistry 2001, 40 (43), 13060-13067.

(4) Mathur-De Vré, R.; Binet, J. Molecular aspects of tritiated water and natural water in radiation biology. Prog. Biophys. Mol. Biol. 1984, 43 (2), 161-193.

(5) Hunt, G. J.; Bailey, T. A.; Jenkinson, S. B.; Leonard, K. S. Enhancement of tritium concentrations on uptake by marine biota: experience from UK coastal waters. J. Radiol. Prot. 2010, 30, 73-83.

(6) McCubbin, D.; Leonard, K. S.; Bailey, A.; Williams, J.; Tossel, P. Incorporation of organic Tritium $(3 \mathrm{H})$ by marine organisms and sediment in the Severn estuary/Bristol Channel (UK). Mar. Pollut. Bull. 2001, 42 (10), 852-863.

(7) Morris, J. E. Organically bound tritum in sediments from the Severn estuary, U.K. Thesis, Southampton University, 2006.

(8) Warwick, P. E.; Croudace, I. W.; Morris, J. E.; Dyer, F. M.; Howard, A. G.; Cundy, A. B. Organically-bound tritium (OBT) dispersion and accumulation in Severn Estuary sediments; R01034; Food Standards Agency Report R01034: 2002; pp 1-58.

(9) Croudace, I. W.; Warwick, P. E.; Morris, J. E. Evidence for the preservation of technogenic tritiated organic compounds in an estuarine sedimentary environment. Environ. Sci. Technol. 2012, 46 (11), 57045712.

(10) Gontier, G.; Siclet, F. Organic tritium in freshwater ecosystems: Long-term trends in the environment of French nuclear power plants (in French). Radioprotection 2011, 46 (4), 457-491.

(11) Jean-Baptiste, P.; Baumier, D.; Fourré, E.; Dapoigny, A.; Clavel, B. The distribution of tritium in the terrestrial and aquatic environments of the Creys-Malville nuclear power plant (2002-2005). J. Environ. Radioact. 2007, 94 (2), 107-118.

(12) Bailly du Bois, P.; Dumas, F. Fast hydrodynamic model for medium- and long-term dispersion in seawater in the English Channel and southern North Sea, qualitative and quantitative validation by radionuclide tracers. Ocean Modelling 2005, 9, 169-210.

(13) Bailly du Bois, P.; Dumas, F.; Solier, L.; Voiseux, C. In-situ database toolbox for short-term dispersion model validation in macrotidal seas, application for 2D-model. Cont. Shelf Res. 2012, 36, 63-82.

(14) Fiévet, B.; Plet, D. Estimating biological half-lives of radionuclides in marine compartments from environmental time-series measurements. J. Environ. Radioact. 2003, 65, 91-107.

(15) R Development Core Team R: A language and environment for statistical computing. R Foundation for Statistical Computing. http:// www.R-project.org/

(16) Baty, F.; Delignette-Muller, M.-L. nlstools: Tools for nonlinear regression diagnostics, $\mathrm{R}$ package version $0.0-13 ; 2012$.

(17) Bailly du Bois, P.; Guéguéniat, P. Quantitative assessment of dissolved radiotracers in the English Channel: sources, average impact of la Hague reprocessing plant and conservative behaviour (1983, 1986, 1988 and 1994). Cont. Shelf Res. 1999, 19, 1977-2002. 
(18) Bailly du Bois, P.; Dumas, F. In Dissolved radionuclide measurements used for qualitative and quantitative calibration of hydrodynamic models in the English. Channel and the North Sea; validation of "TRANSMER" model., 34 th International Liège Colloquim on Ocean Dynamics Tracer methods in geophysical fluid dynamics, Liège, May 6 10, 2002; Liège, May 6 - 10, 2002.

(19) Benga, G. Water channel proteins (later called aquaporins) and relatives: Past, present, and future. IUBMB Life 2009, 61 (2), 112-133.

(20) Hachez, C.; Chaumont, F. Aquaporins: A family of highly regulated multifunctional channels. Adv. Exp. Med. Biol. 2010, 679, 117.

(21) Campbell, E. M.; Ball, A.; Hoppler, S.; Bowman, A. S. Invertebrate aquaporins: A review. J. Comp. Physiol., B 2008, 178 (8), 935-955.

(22) Cerdà, J.; Finn, R. N. Piscine aquaporins: An overview of recent advances. J. Exp. Zool., Part A 2010, 313 A (10), 623-650.

(23) Maurel, C. Plant aquaporins: Novel functions and regulation properties. FEBS Lett. 2007, 581 (12), 2227-2236.

(24) World Health Organization. Guidelines for Drinking-Water Quality, 4th ed.; Geneva, Switzerland, 2011; p 541.

(25) Hagger, J. A.; Atienzar, F. A.; Jha, A. N. Genotoxic, cytotoxic, developmental and survival effects of tritiated water in the early life stages of the marine mollusc Mytilus edulis. Aquat. Toxicol. 2005, 74 (3), $205-217$.

(26) Jha, A. N.; Dogra, Y.; Turner, A.; Millward, G. E. Impact of low doses of tritium on the marine mussel, Mytilus edulis: Genotoxic effects and tissue-specific bioconcentration. Mutat. Res., Genet. Toxicol. Environ. Mutagen. 2005, 586 (1), 47-57.

(27) Jha, A. N.; Dogra, Y.; Turner, A.; Millward, G. E. Are low doses of tritium genotoxic to Mytilus edulis? Mar. Environ. Res. 2006, 62, S297S300.

(28) Jaeschke, B. C.; Millward, G. E.; Moody, A. J.; Jha, A. N. Tissuespecific incorporation and genotoxicity of different forms of tritium in the marine mussel, Mytilus edulis. Environ. Pollut. 2011, 159 (1), 274280.

(29) Adam-Guillermin, C.; Pereira, S.; Della-Vedova, C.; Hinton, T.; Garnier-Laplace, J. Genotoxic and reprotoxic effects of tritium and external gamma irradiation on aquatic animals. Rev. Environ. Contam. Toxicol. 2012, 220, 67-103.

(30) Dallas, L. J.; Keith-Roach, M.; Lyons, B. P.; Jha, A. Assessing the impact of ionizing radiation on aquatic invertebrates: A critical review. Radiat. Res. 2012, 177, 693-716. 
Tritium releases in the English Channel

\begin{tabular}{lccc}
\hline \multicolumn{1}{c}{ Sampling } & HTO & uncertainty \\
Location & Date & Bq.L ${ }^{-1}$ & 2 sigma \\
\hline Roscoff & $26 / 07 / 2010$ & 0.21 & 0.01 \\
Concarneau & $27 / 07 / 2010$ & 0.20 & 0.01 \\
Atlantic Ocean, loc\#1 & $07 / 09 / 2010$ & 0.14 & 0.01 \\
Atlantic Ocean, loc\#2 & $31 / 08 / 2010$ & 0.10 & 0.01 \\
Atlantic Ocean, loc\#3 & $02 / 09 / 2010$ & 0.13 & 0.01 \\
Atlantic Ocean, loc\#4 & $03 / 09 / 2010$ & 0.21 & 0.01 \\
Atlantic Ocean, loc\#5 & $01 / 09 / 2010$ & 0.11 & 0.01 \\
Atlantic Ocean, loc\#6 & $03 / 09 / 2010$ & 0.13 & 0.01 \\
\hline
\end{tabular}

Table S1: Seawater HTO data documenting the background activities of Atlantic waters entering the Western English Channel. Atlantic Ocean sampling locations are displayed on Fig.1. 


\section{Figure caption}

Figure S1: Seawater HTO at Goury (Bq.L-1) between Jan. 2009 and Dec. 2011. Comparison between monthly field measurement data (open circles) and hydrodynamic modelling every $10 \mathrm{~min}$ (solid line).

Figure S2: Time-series measurements of tritium in seaweed Laminaria digitata collected at Goury (Left: HTO; Right: OBT). Values are expressed in Bq. $\mathrm{L}^{-1}$, error bars account for measurement uncertainties (2 sigma). Seawater HTO data (dashed line) reported from fig. 2 used as input signal to the model to compute OBT in seaweed (solid line).

Figure S3: Time-series measurements of tritium (HTO and OBT) in Patella sp. collected at Goury. Values are expressed in Bq.L $\mathrm{L}^{-1}$, error bars account for measurement uncertainties (2 sigma). Seawater HTO data (dashed line) are reported from Fig. 2 for comparison. 
Figure S1

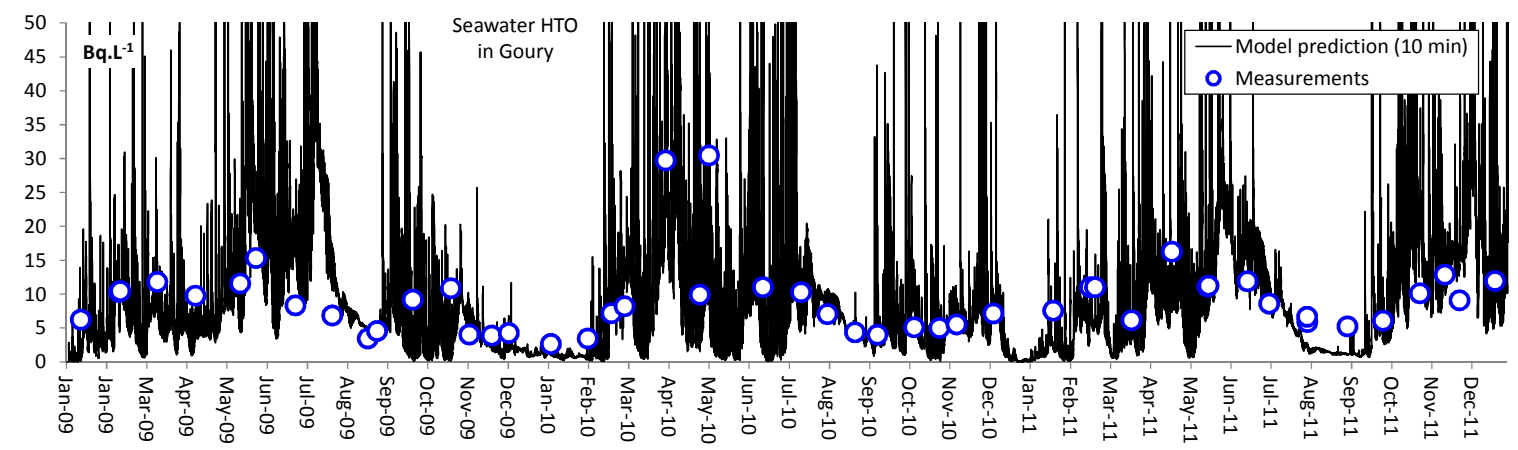

Figure S1: Seawater HTO at Goury (Bq.L-1) between Jan. 2009 and Dec. 2011. Comparison between monthly field measurement data (open circles) and hydrodynamic modelling every 10 min (solid line). 
Figure S2
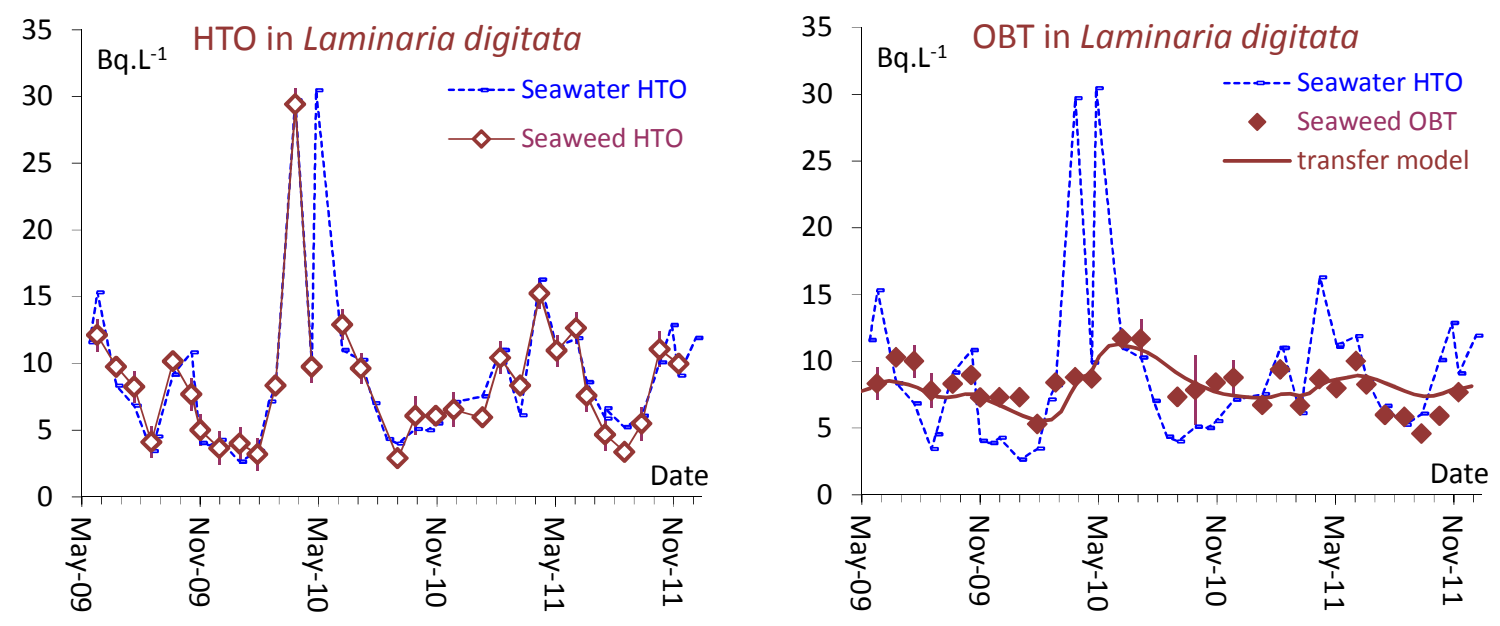

Figure S2: Time-series measurements of tritium in seaweed Laminaria digitata collected at Goury (Left: HTO; Right: OBT). Values are expressed in Bq. $\mathrm{L}^{-1}$, error bars account for measurement uncertainties (2 sigma). Seawater HTO data (dashed line) reported from fig. 2 used as input signal to the model to compute OBT in seaweed (solid line). 


\section{Figure S3}

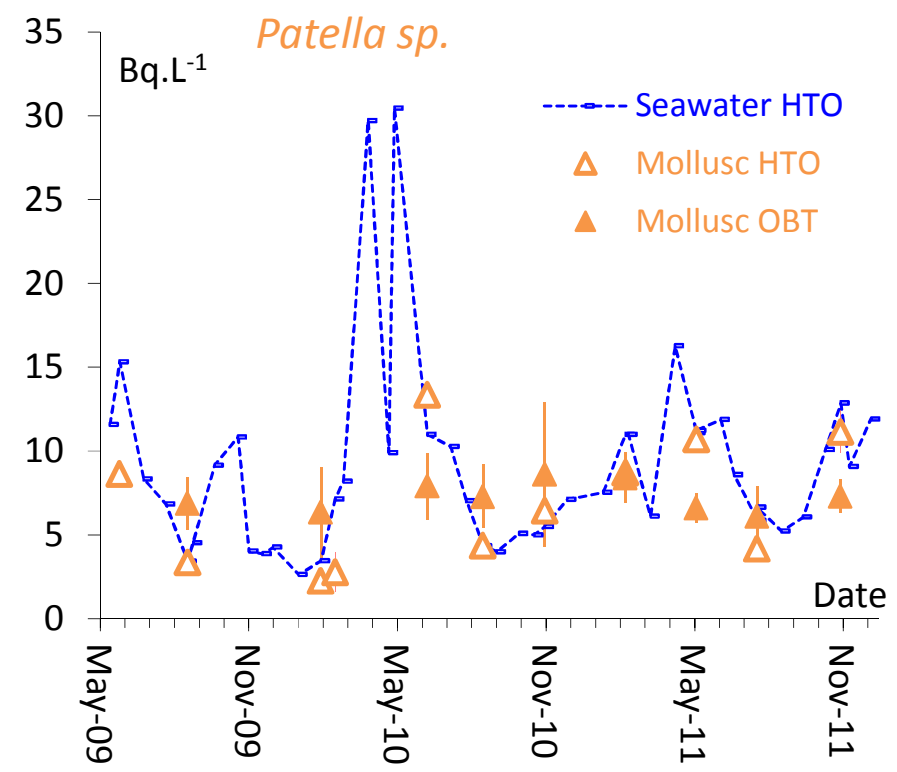

Figure S3: Time-series measurements of tritium (HTO and OBT) in Patella sp. collected at Goury. Values are expressed in Bq. $\mathrm{L}^{-1}$, error bars account for measurement uncertainties (2 sigma). Seawater HTO data (dashed line) are reported from Fig. 2 for comparison. 